\title{
PENGARUH JENIS PAKAN TERHADAP PERTUMBUHAN BULUN DAN PERFORMA LOVE BIRD
}

\section{The Effect of Feed to Feather Growth and Production of Love Bird}

\author{
Drajad Adi Panggayu ${ }^{1)}$, Eko Widodo ${ }^{2)}$ \\ 1) Mahasiswa Fakultas Peternakan, Universitas Brawijaya Jalan Veteran, Ketawanggede, Kec. Lowokwaru, Kota \\ Malang, Jawa Timur, Indonesia 65145 \\ ${ }^{2)}$ Dosen Nutrisi dan Makanan Ternak, Fakultas Peternakan, Universitas Brawijaya Jalan Veteran, \\ Ketawanggede, Kec. Lowokwaru, Kota Malang, Jawa Timur, Indonesia 65145 \\ E-mail: eko.widodo@ub.ac.id \\ Diterima Pasca Revisi: 20 Februari 2021 \\ Layak Diterbitkan: 1 Maret 2021
}

\begin{abstract}
ABSTRAK
Penelitian ini bertujuan untuk mengetahui pengaruh jenis pakan terhadap pertumbuhan bulu, pertambahan bobot badan, konsumsi dan koversi pakan pada love bird serta memberi rekomendasi pakan yang terbaik dan efisien untuk digunakan oleh peternak. Rancangan penelitian ini menggunakan metode RAL (Rancangan Acak Lengkap). Perlakuan terdiri dari 3 jenis pakan (Nutribird A21, Y, Z), masing-masing diulang 7x dan setiap ulangan 1 ekor sehingga diperoleh 21 unit percobaan. Penelitian dilakukan selama 4 minggu. Data hasil penelitian diuji ANOVA. Hasil penelitian menunjukkan bahwa secara kualitatif deskriptif ada perbedaan pertumbuhan bulu namun dari variabel bobot badan dan efisiensi pakan tidak ada pengaruh yang berbeda nyata. Kesimpulannya adalah P1 (Nutribird A21) dengan pertumbuhan bulu yang lebat, indah dan mengkilap, dapat disarankan untuk digunakan peternak.
\end{abstract}

Kata Kunci: Love Bird, Nutribird A21, Y, Z, pertumbuhan bulu

How to Cite:

Panggayu, D. A., \& Widodo, E. (2021). Pengaruh Jenis Pakan Terhadap Pertumbuhan Bulun dan Performa Love Bird. Jurnal Nutrisi Ternak Tropis 4 (1) $15-23$
*Corresponding author:

Eko Widodo

Email: eko.widodo@ub.ac.id

Dosen Nutrisi dan Makanan Ternak, Fakultas Peternakan, Universitas Brawijaya Jalan Veteran, Ketawanggede, Kec. Lowokwaru, Kota Malang, Jawa Timur, Indonesia 65145 


\section{ABSTRACT}

Love Bird is a small bird, the length between 13 to $17 \mathrm{~cm}$ and weight of 40 to $60 \mathrm{gs}$ with its social character. Though love birds are seed-eating birds, but currently feed products are commercially available for example Nutribird A21, Y and Z. This study aims to determine the effect of type of feed on feather growth, body weight gain, feed consumption and conversion in love birds which then could be recommended to the farmers. The research design used was Completely Randomized Design (CRD). The treatments consisted of 3 types of feed (Nutribird A21, Y, Z), each of which was repeated 7 times to obtain 21 experimental units. The data are then subjected to ANOVA. The results indicated that qualitative and descriptive observation found different feather growth, but the effects were not significant on body weight and feed efficiency. It is concluded that P1 (Nutribird A21) could be recommended due to the feather is more dense, beautiful and shiny.

Keywords: Love Bird, nutribird A21, Y, Z, feather growth

\section{PENDAHULUAN}

Love Bird merupakan salah satu burung berkicau yang berasal dari Afrika. Love Bird adalah burung yamg memiliki sembilan jenis spesies genus Agapornis (dari bahasa Yunani "agape" yang berarti cinta dan "ornis" yang berarti burung). Burung love bird memiliki warna bulu yang cantik dan indah, memiliki ukuran yang kecil, yaitu sekitar 13 sampai $17 \mathrm{~cm}$ dengan berat 40 sampai $60 \mathrm{~g}$ dan memiliki sifat sosial. Love Bird merupakan burung pemakan biji-bijian. Makanan tambahan lainnya adalah sayursayuran dan buah-buahan (Satriyo, 2017).

Nutrisi yang dibutuhkan oleh love bird harus mengandung karbohidrat, protein, lemak, vitamin dan mineral agar burung dapat tumbuh secara normal. Secara Umum pakan utama meliputi millet merah, millet putih, biji kenari (canary seed), biji oat dan lain - lain, sedangkan untuk pakan tambahan meliputi jagung, kecambah, kangkung, kuaci (biji bunga matahari) dan lain-lain (Pratama, 2019). Lalu secara komersiil, seiring dengan berkembangnya zaman pakan burung love bird terdapat berbagai produk seperti Nutribird A21, Y dan Z.
Pakan Xmempunyai kandungan protein $21 \%$, lemak $8 \%$, serat kasar 3\%, lisin 1,15\%, methionin $\quad 0,53 \%$, threonin $0,80 \%$, triptophan $0,18 \%$, kalsium $0,9 \%$, phospor $0,6 \%$, magnesium $0,17 \%$ dan mengandung vitamin A, D, E, K, B komplek, C dan lainlain. $X$ juga diperkaya adanya kandungan probiotik dan enzim didalamnya, sehingga proses pencernaan dalam burung dapat bekerja dengan baik. Di lain pihak, Y memiliki kandungan protein sebanyak $20.80 \%$, karbohidrat sebanyak 13,1\%, lemak 7.3\%, vitamin (A, B1, B2, B6, B12 dan $\mathrm{C}$ ) dan mineral ( $\mathrm{Ca}, \mathrm{P}, \mathrm{Na}, \mathrm{Cu}, \mathrm{Zn}$ dan $\mathrm{Mg}$ ). Sedangkan pakan $Z$ mempunyai kandungan protein minimal sebesar $21 \%$, lemak minimal 5\% dan serat maksimal 3\%, tentu juga mengandung berbagai vitamin dan mineral. Dalam penelitian Satriyo (2017) menyatakan bahwa pakan Xmenghasilkan bobot sebesar 47,2 g, konsumsi pakan sebanyak 47,2g dan konversi pakan sebanyak $6,2 \mathrm{~g}$ dengan angka kematian sebesar $40 \%$.

Berdasarkan uraian tersebut, penelitian ini mengkaji tentang pengaruh jenis pakan terhadap pertumbuhan bulu, pertambahan bobot badan, konsumsi dan 
konversi pakan pada love bird sehingga diharapakan dapat memberi informasi kepada mahasiswa dan para peternak agar mendapat jenis pakan yang terbaik dan efisien untuk digunakan.

\section{MATERI DAN METODE}

\section{Materi}

Materi yang digunakan untuk penelitian ada 3 (tiga) yaitu, $X \pm 1$ kemasan (Netto $3 \mathrm{~kg}$ ), Y \pm 4 kemasan (Netto 400 gr) dan $Z \pm 4$ kemasan (Netto 400 gr) yang diperoleh dari e-commerce atau supermarket (Toko Pakan Burung) di Lamongan. Alat yang digunakan dalam penelitian ini adalah kandang baterai sebanyak 21 petak, tempat pakan, timbangan digital, kertas label, spuit, inkubator, gelas ukur, gunting dan sendok. Love bird hasil ternak sendiri sebanyak 21 ekor umur 2 minggu yang tidak dibedakan jenis kelaminnya.

\section{Metode}

Penelitian ini menggunakan metode experiment, dilaksanakan menggunakan Rancangan Acak Lengkap dengan 3 (tiga) perlakuan dan 7 kali ulangan. Pemeliharaan anakan burung dilakukan mulai umur 2 minggu sampai umur 6 minggu. Perlakuan yang diberikan adalah sebagai berikut:

$$
\begin{aligned}
& \text { P1 }=\text { Pakan } X \\
& \text { P2 }=\text { Pakan Y dan } \\
& \text { P3 }=\text { Pakan } Z .
\end{aligned}
$$

\section{Prosedur penelitian}

Pelaksanaan penelitian ini dilakukan 2 (dua) tahap yaitu tahap persiapan dan tahap pemeliharaan. Pada tahap persiapan yang dilakukan yaitu menyiapkan segala hal berupa alat maupun bahan untuk penelitian sedangkan tahap pemeliharaan mulai 2 sampai 6 minggu seperti menimbang pakan yang digunakan untuk penelitian, membuat bubur pakan (air hangat dan pakan dicampur dalam proporsi yang sama) kemudian bubur pakan dimasukkan ke dalam spuit lalu diloloh karena belum dapat makan sendiri.

Pemberian pakan ini dilakukan sebanyak 4 (empat) kali yaitu pagi, siang, sore dan malam. Total dalam sehari konsumsi pakan anakan burung membutuhkan $4 \mathrm{~g}$, oleh karena itu dalam 1 minggu membutuhkan 28g untuk setiap anakannya. Untuk minggu kedua, ketiga dan keempat konsumsi pakan anakan burung dinaikkan yaitu masing-masing menjadi sebanyak $2 \mathrm{~g}$ dalam sekali makan/loloh. Sama halnya pada minggu pertama pemberian makan dilakukan sebanyak 4 kali dalam sehari, sehingga total dalam sehari konsumsi pakan sebanyak 8 g. Dalam satu minggu konsumsi pakan anakan burung love bird dibutuhkan sebanyak 56g untuk setiap anakan. Maka dari itu total keseluruhan konsumsi pakan setiap burung love bird mulai minggu pertama hingga minggu keempat sebanyak 196g setiap pakan (Nutribird A21, Y dan Z). Dalam penelitian ini, burung love bird yang digunakan sebanyak 21 ekor burung. Jika setiap burung membutuhkan 196g setiap pakan, maka total untuk seluruh burung yang digunakan mulai minggu pertama penelitian hingga minggu keempat sebanyak 4.116 g (4 Kg 116 g). Selanjutnya dilakukan tahap pemeliharaan, tahap ini anakan love bird dimulai umur 2 (dua) minggu dilakukan penimbangan. Penimbangan bobot badan juga dilakukan tiap minggunya hingga minggu keenam.

\section{Variabel Penelitian}

Variabel yang diamati dalam penelitian ini adalah pertumbuhan bulu, pertambahan bobot badan, konsumsi pakan dan konversi pakan.

\section{Analisis Statistik}

Data diolah menggunakan software Microsoft excel dan dianalisis menggunakan ANOVA dari rancangan acak lengkap apabila terdapat perbedaan 
dilanjutkan dengan uji BNT. Sedangkan, pertumbuhan bulu dianalisis secara kualitatif deskriptif.

\section{HASIL DAN PEMBAHASAN}

\section{Pertumbuhan Bulu}

Bulu merupakan sebuah karakteristik dari seekor unggas, terutama pada burung kicauan salah satunya adalah love bird. Menurut Nash (2008) bulu memilki peran yang penting pada ternak unggas yaitu bulu dapat digunakan untuk terbang, sebagai perlindungan dan sebagai alat mempercantik atau ciri khas unggas tersebut. Pada kontes love bird bulu juga menjadi kreteria dalam kontes. Pada penelitian ini pertumbuhan bulu burung pada minggu pertama pengamatan masih sedikit baru bulu-bulu halus atau bulu kapas, sehingga belum ada perbedaan disetiap perlakuan (pakan) yang diberikan. Pada minggu kedua pertumbuhan bulu burung sudah lumayan tumbuh seperti adanya bulu jarum, bulu dikepala, sayap dan ekor. Minggu kedua ini sudah terlihat adanya perbedaan pertumbuhan bulu namun belum terlalu mencolok. Untuk perlakuan P1 (Nutribird A21) menghasilkan bulu yang lebih rapi, lebat dibandingkan dengan pelakuan jenis pakan yang lainnya.

Pertumbuhan burung pada minggu ketiga sudah mulai memiliki bulu yang lengkap, lebat dan sudah terlihat warna bulunya dan pada pengamatan minggu ini sudah terlihat adanya perbedaan dari setiap perlakuan (pakan) yang diberikan, sehingga dapat dilihat jika pakan yang terlihat berbeda yaitu pada pakan Xyang menghasilkan pertumbuhan bulu yang lebat, rapih, mengkilap. Pada minggu keempat pertumbuhan bulu sudah sempurna baik kepala, leher, sayap, dan ekornya dan warna bulupun sudah pasti tidak ada perubahan lagi dan sudah mulai dapat terbang. Penelitian pada minggu ini memiliki hasil yang sama seperti minggu-minggu sebelumnya yaitu perlakuan (pakan) Xyang memilki pertumbuhan bulu yang sangat lebat, indah, lebih mengkilap dan rapih.

Bulu-bulu pada anakan love bird sudah tumbuh lebat dan memiliki warna yang bermacam-macam. Dimana warna dari burung ini dapat menentukan harga atau nilai jual. Pertumbuhan bulu burung love bird pada minggu ini sudah hampir sempuna. Menurut Kurtini dkk. (2011) menyatakan bahwa warna dan pola bulu adalah karakteristik genetis. Pertumbuhan bulu juga dipengaruhi oleh hormon. Hormon yang penting dalam pembedaan dan pemolaan bulu pada unggas muda dan dewasa adalah tiroksin. Selain itu, hormon estrogen dan testosteron juga berpengaruh dalam pertumbuhan bulu dan pembedaan bulu jantan maupun betina. Pada penelitian minggu ini memilki hasil yang sama seperti minggu ketiga, dimana pakan A (Nutribird A21) memilki pertumbuhan bulu yang sangat lebat, indah dan lebih mengkilap dibandingkan dengan pakan B (Y) dan juga pakan C (Z).

Berdasarkan hasil yang diperoleh tersebut, perlakuan P1 (Nutribird A21) menghasilkan pertumbuhan bulu yang lebat, warna yang indah, mengkilap dan rapih. Xmemiliki kandungan yang lebih bagus karena mengandung komposisi nutrisi seimbang yg dibutuhkan oleh anak burung, seperti protein, mineral, vitamin (B kompleks), enzim, probiotik dan trace element. Kebutuhan akan sumber protein meningkat, karena bulu terdiri atas keratin yang terbuat dari protein dan berpengaruh hampir sepersepuluh berat badan (Cooper dan Harison, 1994; North and Bell, 1990). Menurut Susiloharjo (1990) bahwa vitamin B kompleks sangat berperan pada pergantian bulu. 


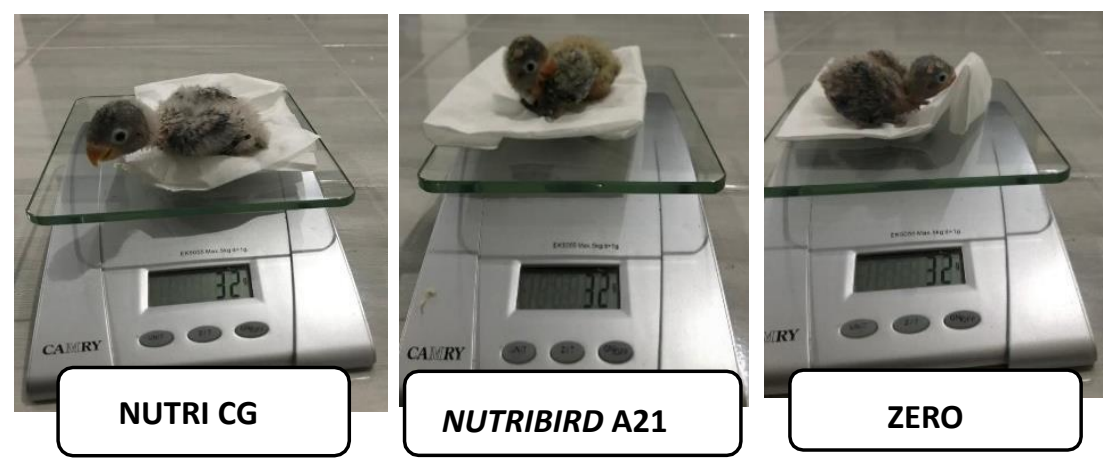

Gambar 1. menunjukkan perbedaan pertumbuhan bulu tersebut dengan berbagai perlakuan pakan.
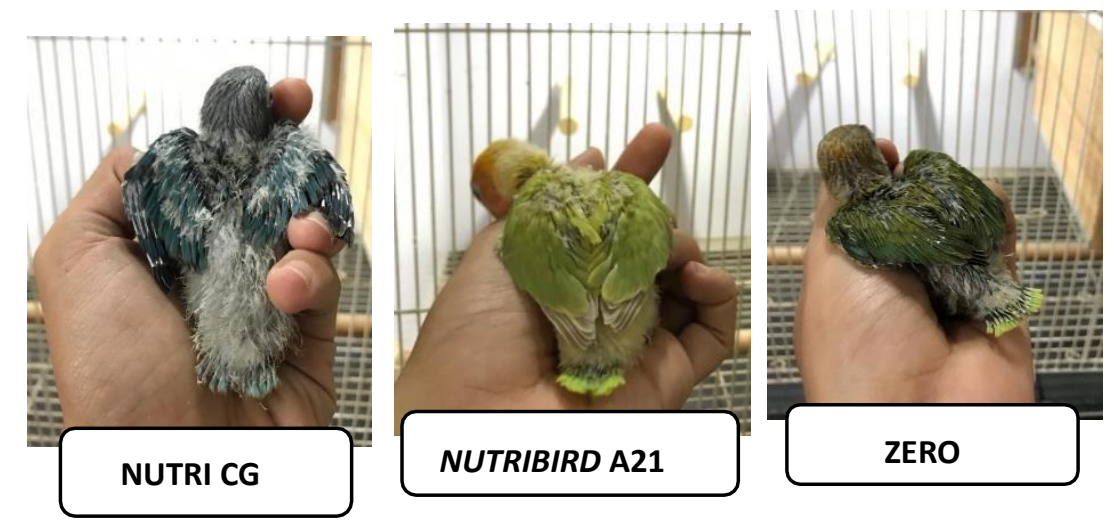

Gambar 2. Bulu burung love bird minggu pertama penelitian (umur 3 minggu)
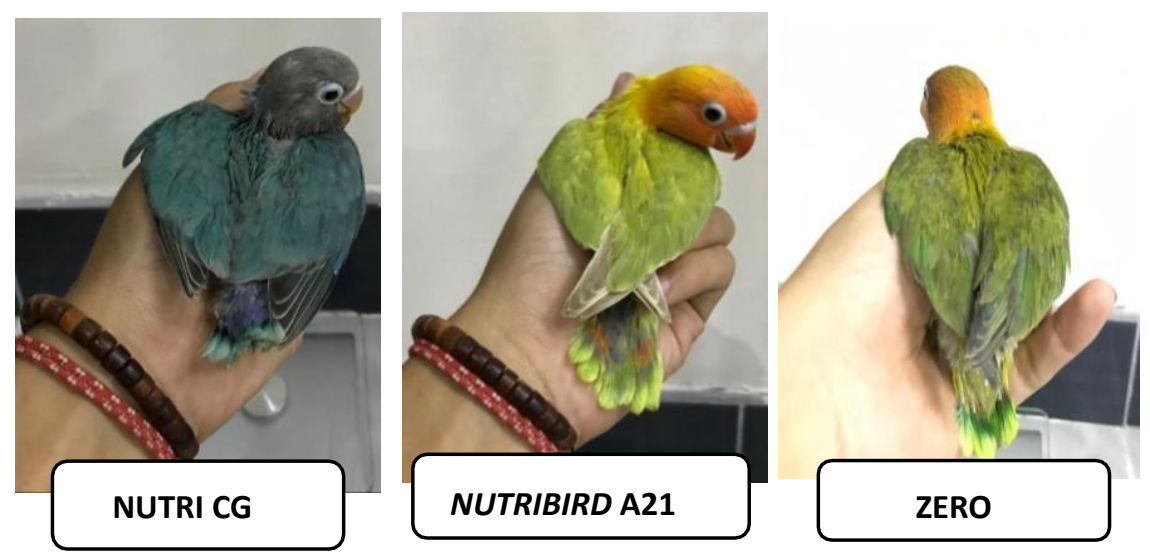

Gambar 3. Bulu burung love bird minggu ketiga penelitian (umur 5 minggu) 

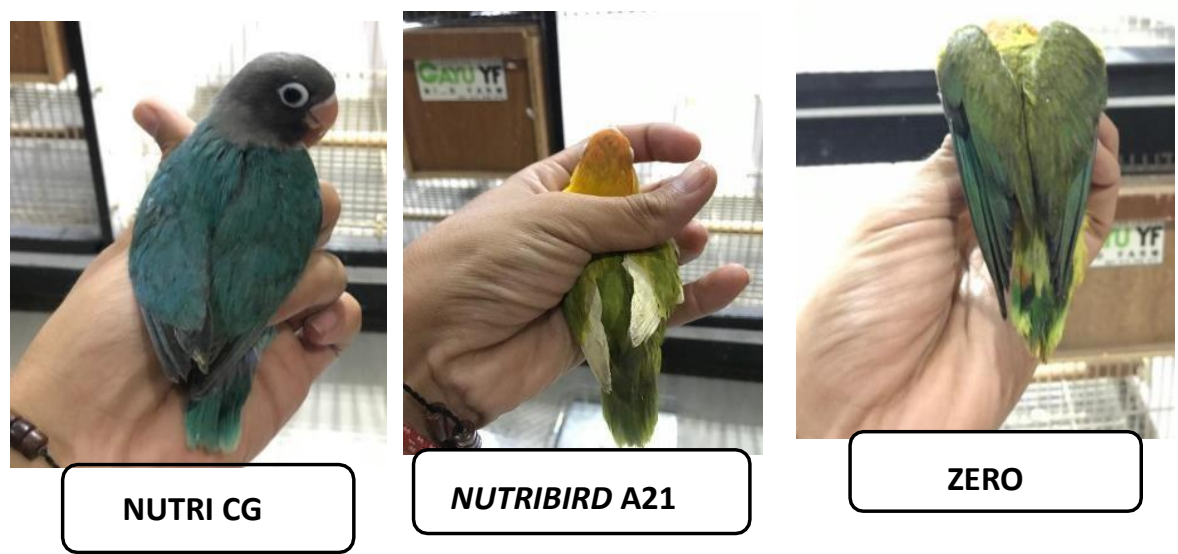

Gambar 4. Bulu burung love bird minggu ketiga penelitian (umur 6 minggu)

\section{Konsumsi Pakan}

Konsumsi pakan merupakan jumlah makanan yang dikonsumsi oleh ternak yang digunakan untuk mencukupi hidup pokok dan untuk produksi hewan tersebut (Tilman dkk., 1991). Pada penelitian ini pakan diberikan untuk frekwensi dan jumlah pemberian yang sama, sehingga tentu saja secara statistik tidak berbeda nyata, karena diberikan dalam jumlah yang sama. Pertimbangan utama adalah ukuran tubuh love bird ini dan tidak mungkin memberikan perlakuan kuantitas pakan karena umurnya juga masih sangat muda dan ukurannya tembolok juga kecil dan baru berkembang. Oleh karena itu, data konsumsi pakan stiap burung adalah sama dan tidak perlu dianalisis statistik. Dalam penelitian ini pakan diberikan secara diloloh, sesuai praktek yang dilakukan peternak, dengan kuantitas sebanyak $1 \mathrm{~g}$ untuk setiap anakan dalam sekali makan pada umur hingga 3 minggu. Dalam sehari pemberian makan anakan burung dilakukan sebanyak 4 kali yaitu pagi, siang, sore dan malam. Pemberian pakan dinaikkan menjadi $2 \mathrm{~g}$ mulai umur 3 minggu hingga 6 minggu. Pemberian pakan terhadap burung, tergantung kapasitas tembolok burung. Pemberian pakan terlalu banyak akan membuat tembolok terlalu penuh maka akan dimuntahkan. Jika terlalu sedikit/kurang maka burung akan cepat lapar dan kurang nutrisi (Anonimous, 2019). Dengan bertambahnya umur dan bobot badan selama periode pertumbuhan, konsumsi akan terus meningkat sehubungan dengan meningkatnya kebutuhan zat makanan untuk hidup pokok dan pertumbuhan. Menurut Tillman et al., (1991) bahwa sifat khusus unggas adalah mengkonsumsi pakan untuk memenuhi kebutuhan energi sehingga jumlah makanan yang dimakan tiap harinya cenderung berhubungan erat dengan kadar energinya.

\section{Pertambahan Bobot Badan}

Pertambahan bobot badan merupakan selisih dari bobot akhir dengan bobot badan awal pada periode waktu tertentu (dalam penelitian ini minggu ke 2 sampai ke 6). Hasil analisa statistik menunjukkan bahwa perlakuan jenis pakan memberikan pengaruh tidak nyata $(\mathrm{P}<0,05)$ terhadap pertambahan bobot badan, hasilnya dapat dilihat pada tabel berikut ini: 
Tabel 1. Pengaruh jenis pakan terhadap pertambahan bobot badan love bird

\begin{tabular}{ccccc}
\hline Perlakuan & Minggu 1 (g/ekor) & Minggu 2 (g/ekor) Minggu 3 (g/ekor) & Minggu 4 (g/ekor) \\
\hline Pakan A & $27,86 \pm 9,21$ & $41,29 \pm 5,56$ & $47,00 \pm 2,16$ & $51,33 \pm 3,51$ \\
Pakan B & $26,00 \pm 10,30$ & $37,14 \pm 5,40$ & $44,29 \pm 5,47$ & $46,33 \pm 7,37$ \\
Pakan C & $25,86 \pm 11,55$ & $40,71 \pm 4,31$ & $46,29 \pm 2,69$ & $51,00 \pm 2,00$ \\
\hline
\end{tabular}

Berdasarkan tabel diatas pada minggu pertama menunjukkan bahwa hasil dari pertambahan bobot badan tertinggi pada $\mathrm{P} 1$ yaitu $X$ sebesar 27,86 g, sedangkan bobot badan terendah yaitu $\mathrm{P} 3(Z)$ sebesar $25,86 \mathrm{~g}$. Untuk minggu kedua disebutkan bahwa jenis P1 (Nutribird A21) merupakan jenis pakan yang menghasilkan bobot badan tertinggi pula yang membuat bobot badan love bird meningkat yaitu sebesar 41,29 g dan untuk perlakuan jenis pakan terendah yang mempengaruhi bobot badan yaitu pada jenis P2 (Y) sebesar 37,14 g. Untuk minggu ketiga dan ke empat, hasil pertambahan bobot badan pada love bird juga masih konsisten, bobot badan yang tertinggi ditunjukkan pada P1 yaitu Nutribird A21.

Hasil untuk minggu ketiga pada perlakuan P1 (Nutribird A21) yaitu 47,00 g dan untuk hasil terendah pada perlakuan P2 (Y) yaitu 44,29 g, sedangkan pada minggu keempat untuk P1 (Nutribird A21) sebesar $51,33 \mathrm{~g}$ dan terendah pada perlakuan P2 (Y) sebesar 46,33 g. Perbedaan dalam pertambahan bobot badan ini mencerminkan kualitas pakan yang digunakan terutama terkait dengan mikro nutrient yang terkandung. Menurut Campbell (1985) bahwa bobot badan dipengaruhi oleh kualitas pakan, kemampuan ternak mencerna pakan dan untuk mengubah pakan menjadi daging, keseimbangan nutrisi pakan, ukuran tubuh, temperatur lingkungan, bentuk fisik pakan dan jenis kelamin. Kualitas pakan yang dikonsumsi oleh ternak sangat menentukan pertambahan bobot badan sehingga berpengaruh terhadap efisiensi suatu usaha peternakan (Widodo, 2018).

\section{Konversi Pakan}

Konversi pakan merupakan perbandingan antara jumlah konsumsi pakan dengan pertambahan bobot badan dalam satuan waktu tertentu (Anggorodi, 1985). Pada penelitian ini analisa konversi pakan dapat dilihat pada grafik berikut ini:

Tabel 2. Hasil Konversi Pakan Burung Setiap Minggu

\begin{tabular}{ccccc}
\hline Perlakuan & Minggu 1 (g/ekor) Minggu 2 (g/ekor) & Minggu 3 (g/ekor) & Minggu 4 (g/ekor) \\
\hline Pakan A & 1,01 & 1,36 & 1,19 & 1,09 \\
Pakan B & 1,08 & 1,51 & 1,26 & 1,21 \\
Pakan C & 1,08 & 1,38 & 1,21 & 1,10 \\
\hline
\end{tabular}

Berdasarkan grafik diatas hasil dari konversi pakan pada minggu pertama penelitian tertinggi pada Pakan $\mathrm{C}$ yaitu $Z$ sebesar 1,08 g, sedangkan konversi pakan terendah yaitu P1 (Nutribird A21) sebesar 1,01 g. Konversi pakan minggu kedua yang tertinggi adalah P2 (Y) dan terendah pada P1 (Nutribird A21). Pada minggu ketiga dan keempat juga menghasilkan konversi pakan yang tertinggi pada P2 (Y) dan konversi yang terendah yaitu P1 (Nutribird A21). Hal ini sesuai dengan pernyataan Steffens (1989), semakin kecil nilai FCR (Food Conversion Ratio) mempunyai arti bahwa semakin efisien pemanfaatan pakan, kualitas pakan dapat diketahui melalui konversi 
pakan karena nilai FCR memberikan gambaran tentang efisiensi penggunaan pakan untuk pertumbuhan.

Hasil dari analisis ragam (ANOVA) menunjukkan bahwa perlakuan jenis pakan memberikan pengaruh tidak nyata terhadap konversi pakan (FCR). Nilai konversi pakan yang efisien yaitu pada P1 (Nutribird A21) dengan memiliki nilai konversi yang rendah. Nilai konversi pakan menunjukkan seberapa efisen pakan dapat dikonversi atau dimanfaatkan oleh kultivan budidaya secara efisien menjadi bobot badan dan pertumbuhan bulu (Septian dkk., 2013). Pakan Xbukan hanya memiliki kandungan probiotik dan enzim, melainkan juga memiliki kandungan protein yang tinggi. Efisiensi protein dipengaruhi oleh kualitas protein yang ada dalam pakan. Hal tersebut sejalan dengan pernyataan Subandiyono dan Hastuti (2010), yang mengungkapkan bahwa protein yang berkualitas adalah protein yang mempunyai nilai kecernaan tinggi.

\section{KESIMPULAN}

Berdasarkan hasil analisis penelitian yang telah dilakukan yaitu pengaruh jenis pakan yang berbeda terhadap pertumbuhan bulu, pertambahan bobot badan, konsumsi pakan dan konversi pakan didapatkan kesimpulan bahwa pakan yang terbaik dan efisien bagi love bird adalah P1 (Nutribird A21).

\section{DAFTAR PUSTAKA}

Anggorodi, R. (1985). Ilmu Makanan Ternak Unggas. Universitas Indonesia.

Anonimous. (2019). Perawatan Baby Burung Falk/Cockatiel.

Campbell, B. E. L. (1985). A Dictionary of
Birds. the British Ornithologists Union.

Cooper, J.E \& Harrison, G. (1994). Dermathology. Dalam: Avian Medicine: pronciples \& Application. Wingers.

Kurtini, T., K. N. (2011). Produksi Ternak Unggas. Anugrah Utama Raharja.

Nash, H. (2008). Feather types, anatomy \& molting.

North, M. O. (1990). Commercial Chicken Productin Man-ual. 4th Ed. Chapman \& Hall.

Pratama, M.P., Cholissodin, I., \& Natsir, M. (2019). Optimasi komposisi pakan burung lovebird menggunakan algoritme particle swarm optimimization (PSO). Jurnal Pengembangan Teknologi Informasi Dan Ilmu Komputer, 3, 521-528.

Satriyo, A. A. (2017). Pemberian Pakan Berbeda pada Anakan Burung Lovebird dengan Metode HF (Handfeeding). Fakultas Peternakan Universitas Nusatara PGRi Kediri.

Septian, R., Samidjan, I., \& Rachmawati, D. (2013). Pengaruh pemberian kombinasi pakan ikan rucah dan buatan yang diperkaya vitamin e terhadap pertumbuhan dan kelulushidupan kepiting soka (Scylla paramamosain). Journal of Aquaculture Management \& Technology, 2(1), 13-24.

Steffens, W. (1989). Principles of Fish Nutrition. Elis Horward Limited.

Subandiyono., \& Hastuti, S. (2010). Nutrisi Ikan. Pengembangan dan Penjaminan Mutu Pendidikan Universitas Diponegoro.

Susiloharjo, P. (1990). Pertumbuahn Bulu Itik Lokal (Anas platyrhynchos) Betina Yang Menua. Institut Pertanian Bogor. 
Tillman, A.D., Hartadi., \& Reksodiprojo, S. P. (1991). Ilmu Makanan Ternak Dasar. Gadjah Mada University Press.
Widodo, E. (2018). Ilmu Nutrisi Unggas. UB Press. 